\title{
Współczesna architektura niemiecka w kontekście wybranych pism filozoficznych
}

\author{
Aleksander Serafin \\ Instytut Architektury i Urbanistyki, Wydział Budownictwa, Architektury i Inżynierii Środowiska, \\ Politechnika Lódzka,e-mail: aleksander.serafin@p.lodz.pl
}

Streszczenie: Architektura znajduje się współcześnie pod wyraźnym wpływem filozofii. Niektóre wzory myślenia stały się inspiracją dla projektantów, inne posłużyły za usankcjonowanie już zrealizowanych obiektów architektonicznych. Tekst przedstawia zatem architektoniczny wyraz różnych nurtów widocznych w literaturze poświęconej estetyce i filozofii w ogóle. Dyskusji poddano motywy, które odnoszą się do ciągłości i tradycji oraz kwestie złożoności i różnicy. Te dwa różne ujęcia zdają się odnajdywać wspólny mianownik w pismach Martina Heideggera.

Słowa kluczowe: architektura, filozofia, teoria, współczesność.

\section{Wprowadzenie}

Architektura jako dziedzina spajająca technikę i sztuki piękne, na przestrzeni wieków odpowiadała za materializację zjawisk ogólnokulturowych. Poza wszelką wątpliwością pozostaje zatem kwestia wpływu głosu filozofów na sztukę budowania. Kształt współczesnej architektury zdaje się stanowić zapis, w którym zakodowano określone dążenia cywilizacji.

Analizując współczesną europejską literaturę poświęconą nie tylko estetyce, ale także filozofii w ogóle, można zaobserwować, że pewne jej aspekty stały się źródłem inspiracji architektów, bądź post factum usankcjonowały pewne idee wyrażone za pomocą formy architektonicznej. Znane są też przypadki bezpośredniej współpracy pomiędzy filozofami $\mathrm{i}$ architektami, tak jak miało to miejsce w sytuacji opracowywania przez architekta Bernarda Tschumiego wspólnie z fillozofem Jacquesem Derridą słynnego projektu Parku de la Villette w Paryżu (projekt:1983, realizacja: 1998). Na kanwie tej kooperacji Derrida w słynnym eseju „Point de folie - Maintenant l'architecture”, towarzyszącym publikacji „La Casa Vide: La Villette" Tschumiego z 1985 roku, wyjaśniał pojęcia różnicy i powtórzenia, które nadały określoną symbolikę zrealizowanej architekturze zespołu [1, s. 42.].

Rozważając kwestię interakcji literatury filozoficznej i myśli architektonicznej należy jednak wskazać na zróżnicowane efekty współdziałania tych dziedzin wobec formy architektonicznej, która zdaje się być ostatecznym rezultatem omawianego zjawiska.

\section{Myśl intuicjonistyczna}

Przyjmując historyczny punkt postrzegania myśli architektonicznej, należałoby w pierwszej kolejności przywołać stanowisko Henriego Bergsona jako jednego z wpływowych przedstawicieli filozofii francuskiej. Jego myśl charakteryzuje promocja intuicyjnego postrzegania i przedstawiania. Bergson pisał, że ,„przez »obraz« rozumiemy pewne istnienie, 
które jest czymś więcej niż to, co idealista nazywa »wyobrażeniem«, lecz mniej niż to, co realista nazywa »rzeczą«" [2, s. 11.]. Intuicjonizm Bergsona z założenia ograniczony swym zakresem do epistemologii nie wpłynął na architekturę w sposób bezpośredni, ale stał się podatnym gruntem dla rozwoju intencjonalności. Bergson pisał bowiem, że ,praca intelektualna polega na przeprowadzeniu tego samego przedstawienia przez różne poziomy świadomości w kierunku od abstrakcji do konkretu, od schematu do obrazu" [3, s. 217-218.]. Teoria Bergsona oparta na założeniu organicznej natury intuicji wydaje się zatem kluczowa w kwestii przesądzenia o aktywnym stosunku umysłu do przedmiotu, co jest domeną intencjonalności. Jean Paul Sartre pisał w „Wyobraźni” (L’imaginaire, 1940): „To co rzeczywiste, nigdy nie jest piękne. Piękno jest wartością, którą można przykładać tylko do wyobrażenia” [4, s. 279.]. Dlatego też innym razem pyta przekornie: „Czyż katedra nie jest po prostu tą masą rzeczywistego kamienia dominującą nad okolicznymi dachami?” [4, s. 277.], zwracając tym samym uwagę na to, że architektura wyraża się poprzez swoistą „wartość dodaną" w stosunku do wytworu materialnego.

\section{Dwa systemy intencjonalne}

Andrzej P. Bator zwraca uwagę, że w dziedzinie estetyki intencjonalność wyraża się w dwóch systemach: tomizmu i fenomenologii [5, s. 80.]. Pierwszy z wymienionych reprezentuje tradycję, dla której głównym odniesieniem jest filozofia chrześcijańska rozwijająca wątki arystotelesowskie. Na polu architektury ten typ myślenia reprezentują Nowi Klasycyści [6, s. 209-210.]. Aspekt etyczny tej filozofii stawia piękno (wraz z wartościami takimi jak prawda i dobro) w roli atrybutu bytu, co w kwestii architektury zdaje się afirmować całą triadę piękna, użyteczności i trwałości, o której pisał Witruwiusz [7, s. 32.]. Robert Stern, jako jeden z czołowych przedstawicieli tego nurtu w architekturze, pisał jednak, że „klasycyzm nie jest nieodłącznie tożsamy z konkretną ideologią czy przez nią skażony, ale raczej stanowi destylację najlepszych osiągnięć społeczeństwa" [8, s. 216-217.]. Inny istotny aspekt to uznanie wyższości instynktów poznawczych nad pożądaniem, co zdaje się pozostawać w opozycji do większości nurtów kultury nowoczesnej, która została ukonstytuowana poprzez ekspresjonizm.

Drugi natomiast system intencjonalny literatura fenomenologiczna nakreśla wieloaspektowo. Podobnie jak w ujęciu tomistycznym, nie bez znaczenia w stosunku do architektury pozostaje wymiar etyczny. Jak zauważa Miłosz Zieliński, schemat aksjologiczny Maxa Schelera poprzez dalszy rozwój fenomenologii przyczynił się do określenia systemu wartości w świecie rzeczy materialnych, w tym także dzieł architektonicznych [9, s. 45.]. Kolejny istotny dyskurs fenomenologii opiera się na redukcji wstępnego założenia. Edmund Husserl w pracy „Idea fenomenologii” (Die Idee der Phänomenologie, 1913) pisał, że „każdemu przeżyciu psychicznemu odpowiada [...] na drodze redukcji fenomenologicznej czysty fenomen, ukazujący jego immanentną istotę (wziętą jednostkowo) jako daną absolutną" [10, s. 59.]. Husserlowska próba stworzenia „nauki pierwszej” odpowiada estetycznym poszukiwaniom redukcji dekoracyjnego detalu. Przykładem architektonicznego wyrazu „formy pierwszej" w odniesieniu do tej koncepcji może być pawilon niemiecki wybudowany w 1929 roku przy okazji światowej wystawy w Barcelonie (Fot. 1, projekt:1927, realizacja: 1929, rekonstrukcja: 1986). Idea „oryginalnego porządku” Miesa van der Rohe służyła bowiem przede wszystkim sprowadzeniu formy architektonicznej do jej właściwej istoty [11, s. 521-522.]. Koncepcja polegała ona więc na swoistej redukcji formalnej, której ostateczny produkt był wolny od zbędnych elementów plastycznych. 


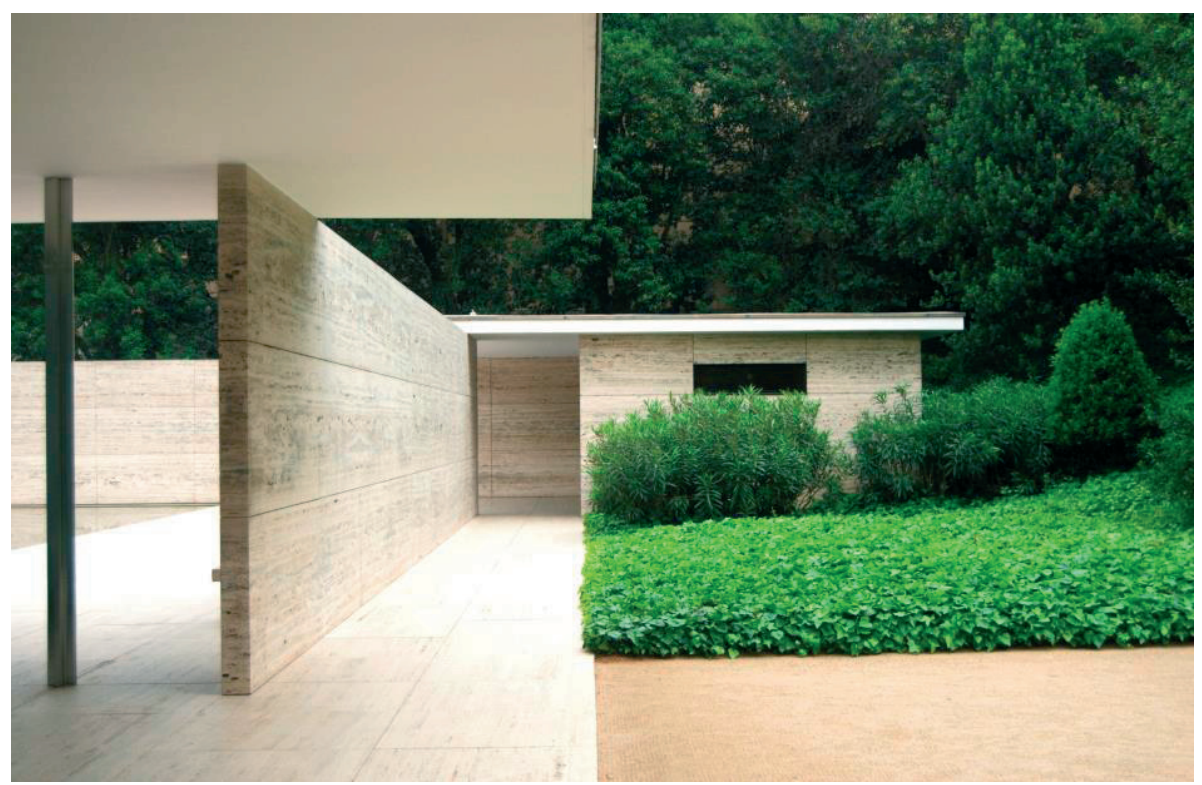

Fot. 1. Mies van der Rohe, Pawilon niemiecki, Barcelona, 1929 (rekonstrukcja 1986), fot. Marceli Serafin

Opisanej powyżej strukturalistycznej interpretacji towarzyszy też taka, która na tle procesu poznawczego uprzywilejowała podmiot w stosunku do przedmiotu. Fenomenologia W zakresie estetyki odnosi się bowiem przede wszystkim do fizycznej percepcji dzieła [12, s. 28.]. Do tej kwestii ustosunkowało się wielu filozofów. Maurice Merleau-Ponty na przykład w „Fenomenologii percepcji” (Phénoménologie de la perception, 1945) pisał: „Doznawanie jest tą żywotną komunikacją ze światem, która uobecnia go nam jako swojskie środowisko naszego życia" [13, s. 72.]. Dlatego też innym przedmiotem zainteresowania autorów pism fenomenologicznych jest kwestia „udomowienia przestrzeni”. Kluczowym w tym względzie staje się pojęcie „Heimwelt” wyprowadzone z teorii Husserla [14, s. 411.]. Idąc dalej, Martin Heidegger zakłada że „budowanie jest już samo w sobie zamieszkiwaniem”, a „zamieszkiwanie jest sposobem, w jaki Śmiertelni są na ziemi” [15, s. 320].

Peter Zumthor będący zadeklarowanym przedstawicielem architektonicznego nurtu fenomenologicznego manifestuje w swojej książce „Myślenie architekturą” (Architektur Denken, 1999) następujący pogląd: „Sens, który należy nadać materialnemu tworzywu leży poza granicami reguł kompozycyjnych, a namacalność, zapach i sposób akustycznego wyrażania się materiałów to jedynie składniki języka, w którym mamy się wypowiadać. Sens rodzi się wówczas, gdy w projektowanych przeze mnie budynkach udaje mi się wydobyć specyficzne znaczenia określonych materiałów, które w ten konkretny sposób odczuwane będą tylko w tym jednym jedynym obiekcie" [16, s. 10.]. Kolejny jego tekst (Atmosphären, 2006) zawiera wyrażony przez tego architekta pogląd, zgodnie z którym pomiędzy materiałami wykończeniowymi zachodzi reakcja natury estetycznej, co sprawia, że każdy z nich ma niezliczoną ilość możliwości wyrazu [17, s. 25.]. Tę wrażliwość na stosowność użycia konkretnego budulca, przy jednoczesnym indywidualnym potraktowaniu materiału, Zumthor wykazał nie tylko w projektach mieszkalnych, ale także w wielkomiejskiej realizacji, jaką jest archidiecezjalne muzeum Kolumba w Kolonii (projekt:2003, realizacja: 2007). Podobną narrację przyjęli też Andreas Meck i Stephan Köppel, którzy w kaplicy cmentarnej w monachijskiej dzielnicy Riem (projekt:1997, realizacja: 2000) 
zastosowali kompozycję opartą na minimalistycznym zestawieniu różnorodnych materiałów (Fot. 2). Tym samym autorzy umiejętnie wpisali charakter budynku w istotę przemijania, której z natury rzeczy powinien się on podporządkować. Realizacja ta może być uznana za przykład architektury nurtu fenomenologicznego [18, s. 50.]. Podobnie bowiem, jak w przypadku dzieł Zumthora, także tutaj istotnym czynnikiem jest uwrażliwienie na percepcję pozawzrokową. Dochodzi na przykład do uwypuklenia roli dotyku, jako zmysłu. Także zastosowane tutaj rozwiązania uwrażliwiające na aspekt trwałości, wpisują się w fenomenologiczną zasadę interakcji podmiotu i przedmiotu.

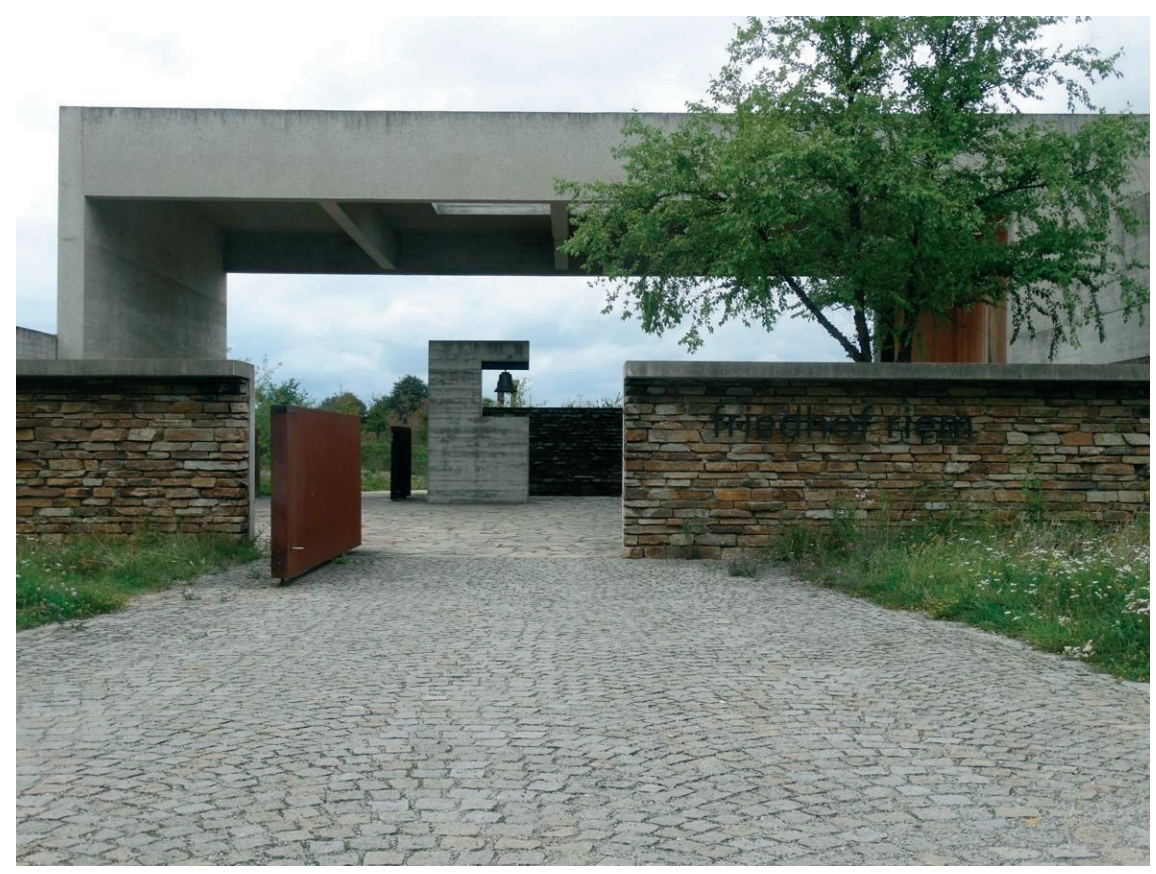

Fot. 2. Andreas Meck, Stephan Köppel, kaplica cmentarna, Monachium, 2000; fot. autor

\section{Literacka koncepcja pęknięć}

Ontologiczny wymiar pism Heideggera sprawia jednak, że w kontekście wpływu literatury fenomenologicznej na architekturę powstaje pewnego rodzaju rozłam ideologiczny. Derrida w książce „Ostrogi: style Nietzschego” (Éperons: les styles de Nietzsche, 1972) napisał, że „Heidegger kontynuuje wyjątkowy w stosunku do metafizyki aspekt działania Nietzschego" [19, s. 58.]. Sam Nietzsche nie unikał nawet bezpośrednich odniesień do stylu. W dziele „Niewczesne rozważania” (Unzeitgemäße Betrachtungen, 1876) pisał, że „kulturą jest przede wszystkiem jedność stylu artystycznego we wszystkich przejawach życiowych” [20, s. 7.]. Jego koncepcja ,wielkiego stylu” została przeciwstawiona „stylowi heroiczno-chełpliwemu" (heroisch-prahlerischen), który - jak pisał Heidegger - był następstwem zdziczałych potrzeb drobnomieszczańskich [21, s. 141.]. Wpisywał się w tę koncepcję między innymi Hans Hollein ze swoją wizją architektury elitarnej i dominującej. Projektant napisał: „Ta architektura nie jest kwestią piękna. Jeżeli w ogóle pożądamy piękna, to nie jest ono raczej pięknem formy, proporcji, a raczej pięknem siły elementarnej 
w znaczeniu sensualnym. Kształt budynku nie wynika z uwarunkowań materiałowych. Budynek nie powinien odzwierciedlać swojej funkcji użytkowej, nie jest wyrazem swojej konstrukcji, nie jest zadaszeniem ani schronieniem. Istota budynku zawiera się sama w sobie. Architektura nie ma przeznaczenia" (tłum. autor) [22, s. 181-182.]. Na kanwie tego wizja Nietzschego materializowała się głównie w postaci szkicu architektonicznego. Koncepcje Holleina z 1960 r., takie jak „Projekt dla miasta” albo „Nadbudowa Wiednia”, stanowią jednoznaczną wizualizację literackich zmagań filozofa, chociaż utopijny charakter nie stwarzał nawet złudzeń, co do możliwości ich realizacji.

\section{Destabilizacja struktury architektonicznej}

Derrida również odwołuje się do Heideggera w kontekście Nietzschego, który głosi, że ,afirmowana jest nowa hierarchia i nowa pozycja wartości. Nowość nie polega na odnowieniu treści hierarchii lub istoty wartości, lecz na przekształceniu samej wartości hierarchii” [19, s. 57-58.]. Odniesienie po raz pierwszy odbywa się na gruncie destabilizacji ustanowionej struktury. Autor „Bycia i czasu” (Sein und Zeit, 1927) promuje bowiem „dokonującą się w horyzoncie kwestii bycia destrukcję przekazanej tradycją zawartości starożytnej ontologii z zamiarem dotarcia do źródłowych doświadczeń” [23, s. 32.]. Heidegger zaznacza jednocześnie, że „w swym aspekcie negatywnym destrukcja nie odnosi się do przeszłości, jej krytyka dotyczy »dnia dzisiejszego«”[23, s. 32.]. Ten właśnie schemat podjęła literatura wpisująca się w nurt ponowoczesny. Michel Foucault na przykład w rozprawie „Archeologia wiedzy” (L’Archéologie du savoir, 1969) zwracał uwagę na tzw. „objawy pęknięć” w obrębie większych struktur, wśród których wymieniał filozoficzne i literackie [24, s. 28.]. Za tą i podobnymi koncepcjami stale podążała myśl architektoniczna. Kolejne, tym razem już zrealizowane projekty Holleina, jak choćby witryna sklepu Herberta Schullina w Wiedniu, zawierały motyw pękniętej ściany fasadowej, który stanowił element kompozycji architektonicznej. Umieszczone w nim połyskujące w złotym kolorze metalowe tuleje nadawały szlachetnego charakteru tej aranżacji, ale jednocześnie wpisywały się w osobliwy „styl technologiczny”, który równolegle reprezentował tenże projektant.

Foucault jednak w granicach swojej koncepcji literackiej definiował także ,jedności architektoniczne”, dla których wykazania „nie jest właściwy opis wpływów tradycji, ciągłości kulturowych, ale raczej opis wewnętrznych spójności, aksjomatów, łańcuchów dedukcyjnych, zgodności" [24, s. 29.]. Widoczna jest zatem różnica dzieląca tę koncepcję od myśli tomistycznej, która skierowała teorię architektoniczną w stronę poszukiwania związków z fundamentami kultury zachodniej i budowania związku z tradycją. Foucault natomiast skupił się na rozstrzyganiu o spójności w obrębie samej struktury, nie zważając na kwestię osadzenia tej struktury w continuum, a tym samym budowania związku z tradycją.

Niezależnie od Foucaulta koncepcję „pęknięć” przedstawia w swojej „Gramatologii” (De la grammatologie, 1967) Derrida. Ta pozycja, będąca w gruncie rzeczy traktatem o architekturze pisma, zawiera ogólną koncepcję formowania struktur w znaczeniu kulturowym. Derrida mianowicie pisze, że „różnica jest artykulacją” [25, s. 101.]. To krótkie stwierdzenie stanowiło przedpole do działania ukierunkowanego na wzbogacenie ponowoczesnej formy architektonicznej. Radykalne stanowisko wyrażone w pismach Foucaulta i Derridy wywołało bowiem bezpośrednią reakcję w architekturze. Współczesną wizualizacją tej koncepcji jest na przykład Wojskowe Muzeum Historyczne Bundeswehry w Dreźnie (Fot. 3, projekt: 2001, realizacja: 2011), gdzie Daniel Libeskind zaprojektował zakłócenie historycznej kompozycji budynku poprzez ekspresyjne wprowadzenie metalowej struktury. Architekt pisze, że „właśnie różnice stanowią harmonię” [26, s. 150.]. 


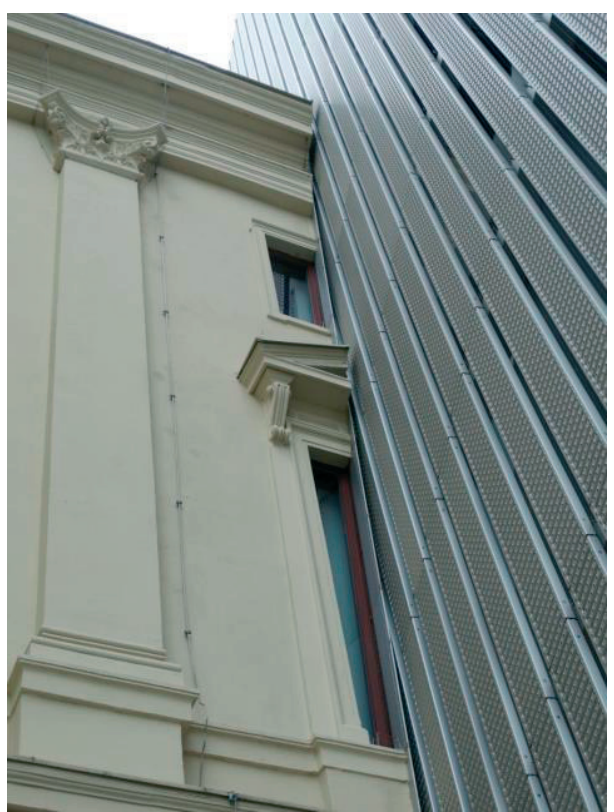

Fot. 3. Daniel Libeskind, Wojskowe Muzeum Historyczne Bundeswehry, Drezno, 2011, fot. autor

Nowa figura narracyjna w kulturze zachodniej pojawiła się jednak przy znacznym udziale architektów niemieckich i austriackich. Paradygmat złożoności, jako dekompozycję logicznego ładu uwydatnił między innymi Günter Behnisch, projektując instytut badawczy Hysolar, część Uniwersytetu w Stuttgarcie (Fot. 4, projekt:1986, realizacja: 1987, renowacja: 2010). Architekt pisał bowiem, że można być odbiorcą ,próbując odczytać [...] coś, co wynosi architekturę ponad rzeczywistość i jej wpływ” [27, s. 33.].

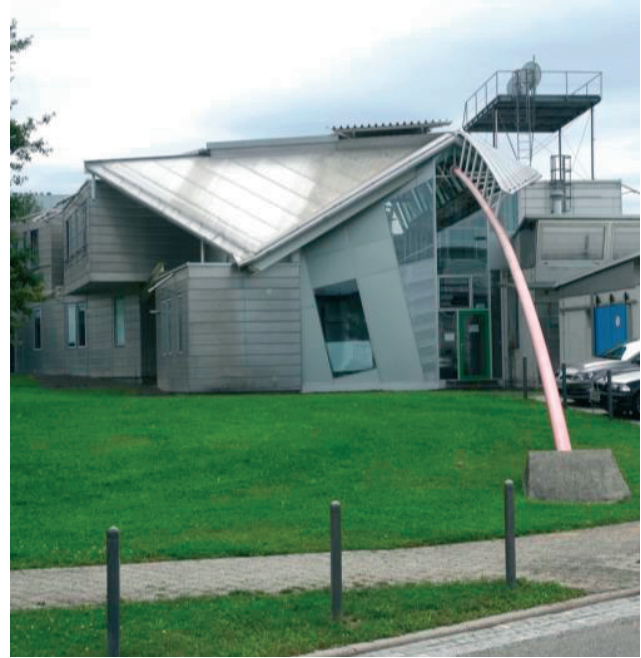

Fot. 4. Günter Behnisch, instytut badawczy Hysolar, Stuttgart, 1987 (renowacja 2010), fot. autor 
Działając w tej samej konwencji Wolfgang Dieter Prix i Helmut Swiczinsky w manifeście (Architektur ist nicht Anpassung, 1983) wyraźnie sprzeciwili się retoryce Heideggera, głosząc: ,architektura żyje przez sekundę, w momencie projektowania. Ona nigdy nie może odwoływać się do przeszłości” (tłum. autor) [28, s. 50.]. Prix wyraźnie zaznacza, że architektura opierająca się na literaturze Derridy przede wszystkim sprzeciwia się dominacji racjonalnej logiki [29, s. 190.]. Wśród najnowszych realizacji efekt tego procesu może obrazować rozbudowa Akademii Sztuk Pięknych w Monachium autorstwa Prixa i Swiczinsky’ego przy udziale Franka Steppera i Hartmuta Hanka (Fot. 5, projekt:1995, realizacja: 2005). Dzisiejsze doświadczenie pozwala więc nakreślić obraz architektury popartej takimi opiniami: „Trudno [...] wskazać punkty w pełni wspólne filozoficznej i architektonicznej dyskusji. Jednak zarówno pisma teoretyczne [...], zrealizowane prace, jak i komentarze krytyków wskazują, że filozoficzna dekonstrukcja nie była dla architektów tylko inspiracją, ale została w ich pracach rozwinięta. Doszło do wystąpienia pewnej równowagi między wpływami filozofii a twórczą reakcją ze strony architektury" [30, s. 4.]. Pisma Derridy i Foucaulta poprzedzone literaturą Nietzschego i Heideggera stały się zatem ostatecznie swoistym katalizatorem dla kulturowych procesów, zorientowanych przeciwnie wobec intencjonalności.

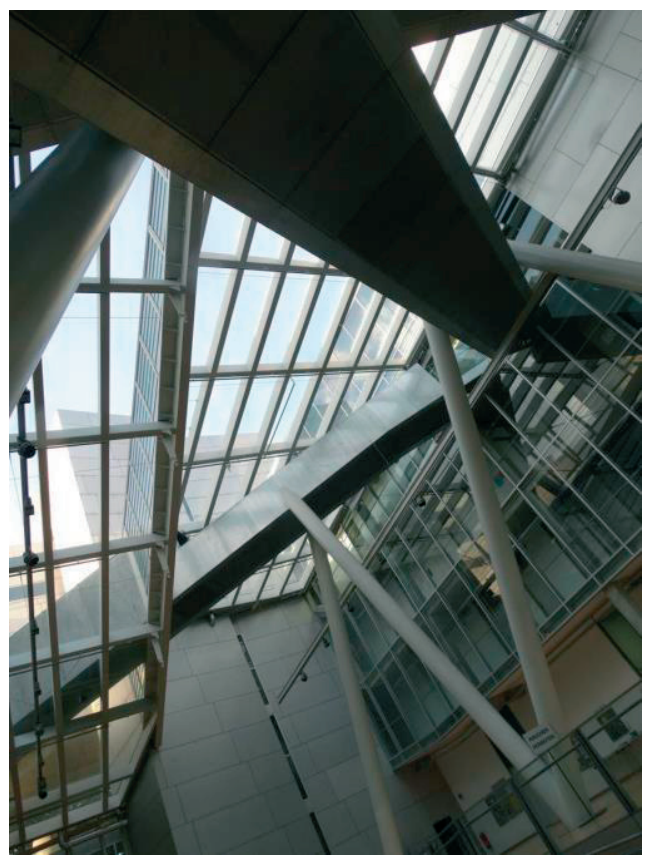

Fot. 5. Wolfgang D. Prix, Helmut Swiczinsky Frank Stepper, Hartmut Hank, Akademia Sztuk Pięknych, Monachium, 2005, fot. autor

\section{Podsumowanie}

Należy zaznaczyć, że architektura jako jedno z dostępnych narzędzi przekazu kulturowego jest niewątpliwie wyrazicielem zapisanej myśli fillozoficznej. Bazę dla ukształtowania spójnego poglądu zdają się jednak stanowić dzieła pisane, ponieważ to one stanowią najbardziej dostępny poligon dla przetwarzania idei. Literatura umożliwiając płynną pole- 
mikę w skali społecznej, odpowiada za krystalizowanie się poglądów, które następnie obejmują inne dyscypliny i obszary ludzkiej działalności, a ostatecznie wkraczają w sferę życia codziennego. Współczesne realizacje architektoniczne dowodzą natomiast tego, że rozwój rynku budowlanego generuje wzrost potencjału pozawerbalnego przekazu informacji. Wysokie nakłady, jakie towarzyszą realizacji architektury sprawiają, że najczęściej przyjmuje ona ,produkt intelektualny”, który jest już wstępnie przetworzony i ugruntowany. Należy przy tym zwrócić uwagę na zjawisko polegające na tym, że realizacja budowlana posiada zwiększony potencjał interpretacyjny w stosunku do dzieła literackiego. Wynika to z nienarracyjnego charakteru formy architektonicznej.

\section{Literatura:}

1. Wąs C. Zagadnienia interpretacji architektury $w$ filozofii Jacquesa Derridy, [w:] Czytanie Derridy. (ed. Małczyński B., Włodarczyk R.). Chiazm, Wrocław 2005.

2. Bergson H. Materia i pamięć. O stosunku ciała do ducha [przeł. W. Filewicz]. Vis-a-vis / Etiuda, Kraków 2012.

3. Bergson H. Energia duchowa [przeł. K. Skorulski, P. Kostyło]. IFiS PAN, Warszawa 2004.

4. Sartre J.P. Wyobrażenie. Fenomenologiczna psychologia wyobraźni [przeł. P. Beylin]. Wydawnictwo Naukowe PWN, Warszawa 2012.

5. Bator A.P. Intencjonalność sztuki. Relacje między fenomenologicznym a tomistycznym ujęciem problemu. Dyskurs 2 (2004-2005) 80-96.

6. Zaguła A. Arystotelesowskie i religijne źródta Nowego Klasycyzmu w architekturze wspótczesnej. Politechnika Łódzka, Łódź 2013.

7. Witruwiusz. O architekturze ksiag dziesięć [przeł. K. Kumaniecki]. Prószyński i S-ka, Warszawa 1999.

8. Stern R.A.M. O stylu, klasycyzmie i pedagogice, [w:] Teorie i manifesty architektury wspótczesnej [tłum. D. Szymczak]. (ed. Jencks C., Kropf K.). Grupa Sztuka Architektury, Warszawa 2013.

9. Zieliński M. Wartości w przestrzeni architektury. Przestrzeń i Forma 22/2 (2014).

10. Husserl E. Idea fenomenologii [przeł. J. Sidorek]. Wydawnictwo Naukowe PWN, Warszawa 2008.

11. Serafin A. Fenomen w architekturze: wobec dyskusji na temat architektury fenomenologicznej, [w:] Wprowadzenie do fenomenologii. Interpretacje, zastosowania, problemy. (ed. Płotka W.). IFiS PAN, Warszawa 2014.

12. Nesbitt K. Theorizing a new agenda for architecture. An anthology of architectural theory 1965-1995, Princeton Architectural Press, New York 1996.

13. Merleau-Ponty M. Fenomenologia percepcji [przeł. M. Kowalska, J. Migasiński]. Aletheia, Warszawa 2001.

14. Świtek G. Gry sztuki z architektura. Wydawnictwo Naukowe Uniwersytetu Mikołaja Kopernika, Torun 2013.

15. Heidegger M. Budować, mieszkać, myśleć, [w:] Martin Heidegger. Budować mieszkać myśleć. Eseje wybrane. (ed. Michalski K.). Czytelnik, Warszawa 1977.

16. Zumthor P. Myślenie architektura [przeł. A. Kożuch]. Karakter, Kraków 2010.

17. Zumthor P. Atmospheres. Architectural environments - surrounding objects [przeł. I. Galbraith]. Birkhäuser, Basel - Boston - Berlin 2006.

18. Serafin A. Wspótczesna architektura sakralna w Monachium - forma $w$ cieniu tradycji fenomenologicznej. Architecturae et Artibus 4 (2015).

19. Derrida J. Ostrogi: style Nietzschego [przeł. B. Banasiak]. Officyna, Łódź 2012.

20. Nietzsche F. Niewczesne rozważania [przeł. L. Staff]. Nakład Jakóba Mortkowicza, Kraków 1912.

21. Heidegger M. Nietzsche. Tom 1 [przeł. A. Gniazdowski, P. Graczyk, W. Rymkiewicz, M. Werner, C. Wodziński]. Wydawnictwo Naukowe PWN, Warszawa 1998. 
22. Pichler W., Hollein H. Absolute architecture, [w:] Programs and manifestoes on 20th-century architecture [tłum. D. Szymczak]. (ed. Conrads U.). The MIT Press, Cambridge 1971.

23. Heidegger M. Bycie i czas [przeł. B. Baran]. Wydawnictwo Naukowe PWN, Warszawa 1994.

24. Foucault M. Archeologia wiedzy [przeł. A. Siemek]. Państwowy Instytut Wydawniczy, Warszawa 1977.

25. Derrida J. O gramatologii [przeł. B. Banasiak]. Officyna, Łódź 2011.

26. Libeskind D. Przelom: przygody $w$ życiu $i$ architekturze [przeł. M. Zawadka]. Wydawnictwa Naukowo-Techniczne, Warszawa 2008.

27. Günter Behnisch - Stuttgart, [w:] Hugo Häring w jego czasach, budowanie w naszych czasach [przeł. E. Wrońska, J. Wroński]. (ed. Otto C.). Miasto Biberach Nadburmistrz Claus W. Hoffmann, Stuttgart 1992.

28. Prix W.D., Swiczinsky H. Architecture is not accommodating, [w:] Get off of my cloud. Wolf D. Prix. Coop Himmelb(l)au. Texts 1968-2005 [przeł. L. Rosenblatt, C. Eckler]. (ed. KandelerFritsch M., Kramer T.). Hatje Cantz, Stuttgart 2005.

29. Prix W.D., Architecture at the end of the twentieth century, [w:] Get off of my cloud. Wolf D. Prix. Coop Himmelb(l)au. Texts 1968-2005 [przeł. L. Rosenblatt, C. Eckler]. (ed. KandelerFritsch M., Kramer T.). Hatje Cantz, Stuttgart 2005.

30. Wąs C., W stronę dekonstrukcji w architekturze. Quart 3 (2010).

\title{
Contemporary German architecture in the context of selected philosophical literature
}

\author{
Serafin, Aleksander \\ Institute of Architecture and Urban Planning, Faculty of Civil Engineering, \\ Architecture and Environmental Engineering, Lodz University of Technology, \\ e-mail: aleksander.serafin@p.lodz.pl
}

\begin{abstract}
Nowadays, philosophy clearly affects the architecture. Some of the patterns of thinking became the inspiration for designers and some others sanctioned certain ideas of the built architectural objects. The paper presents architectural expression of various trends that are evident in the literature that relates to aesthetics and philosophy at all. Both, concepts that refer to the continuity and tradition and the motives of complexity and difference are taken into discussion. The writings of Martin Heidegger seem to be a link between the two different notions.
\end{abstract}

Keywords: architecture, philosophy, theory, contemporaneity. 